\title{
Darkness at Noon: Le Malheur of Capitalism in Bellow's Later Novels
}

\author{
Ramzi Marrouchi ${ }^{1} \&$ Mohd Nazri Latiff Azmi ${ }^{1}$ \\ ${ }^{1}$ Faculty of Languages \& Communication, Universiti Sultan Zainal Abidin, Gong Badak, 21300, Kuala \\ Terengganu, Malaysia \\ Correspondence: Ramzi Marrouchi, Faculty of Languages \& Communication, Universiti Sultan Zainal Abidin, \\ Gong Badak, 21300, Kuala Terengganu, Malaysia. E-mail: ramzi.marrouchi@yahoo.fr
}

\author{
Received: October 30, 2019 Accepted: November 28, 2019 Online Published: December 28, 2019 \\ doi:10.5539/ijel.v10n1p293 URL: https://doi.org/10.5539/ijel.v10n1p293
}

\begin{abstract}
The crisis of capitalism, or what Saul Bellow dubs "the crisis of knowledge", crystallizes the way he deconstructs and subverts the roots of modern American culture. The concepts of "darkness" and "Malheur" embody the tragic fate of capitalism and the end of history to recall Baudrillard and Fukuyama. Colin Davis relates this intellectual atmosphere to Lyotard's theory of "after knowledge" and the postmodern condition, Lévinas's "after ethics" and Althusser's "after hope". Fictionally, Bellow epitomizes this cultural backdrop in modern America by addressing the decline of civility, the agony of the artist, the end of humanism and morality in a society which is dominated by the crowd of low culture to cite Williams. Conceding that the novelist identifies "darkness", "noon", "Malheur" and "capitalism" with Derrida's premises of deconstruction and Foucault's insights about episteme theory and the archeology of knowledge, it becomes then fundamental to underpin how he gives theory and philosophy an overriding role in the purification of humanism from the burden of materialism and capitalistic democracy. Special focus is on Herzog (1964), Mr. Sammler's Planet (1970), Humboldt's Gift (1975) and The Dean's December (1982) as they illustrate Bellow's gestures of deconstructing the negativity of capitalism.
\end{abstract}

Keywords: deconstruction, capitalism, knowledge, archeology, dictatorship

\section{Introduction}

This paper addresses most explicitly the way Bellow deconstructs the roots of American capitalistic culture. Most interestingly, the researchers purport to envision how the novelist shows scrupulous faithfulness to the premises of deconstructionism, and keep reiterating what is to decipher/decode next. The outcome of this subversive gesture, one acknowledges, is that the novelist has been developing a theory of morality and humanism, not like that which is highly generated by apocalyptic theories, but that which the Enlightenment has purported to establish.

Before moving any further, it is fundamental to crystallize a few remarks as they offer another moment of consciousness concerning the author's philosophy of subversion and deconstruction. First, by the time It All Adds Up (1995) was first published, Bellow's subversive gestures were already assured including the way he starts talking about himself and ends up reflecting on other things. Second, by the time one has gone through Bellow's writings and discovered his aesthetic as well as thematic deviations, one becomes be surprised by the 'epistemological' breaks the novelist brings to his early and late views. Consequently, it becomes clear that the novelist strives to establish and develop a theory of subversion and deconstruction that reiterates the unstoppable march of the fate of history and ideas. As long as the task remains unfulfilled and the Enlightenment is not yet over, it is then the purpose of this paper to unveil the way Bellow's intellectual heroes question the roots of American capitalistic culture. The researchers conclude that Bellow shows a theoretical text, the novels, which serves from claims of epistemological mastery, that never dies, unfulfilled, premature, and not yet over.

\section{The Crisis of Capitalism}

\subsection{The Concept of Crisis in Capitalism}

A few years after the publication of The Last Analysis (1965), Bellow crafts his intellectual protagonists (Herzog, Mr. Sammler, Corde, Citrine) to demystify the crisis of capitalism by casting doubt about the condition of knowledge in modern and postmodern America. He introduces the concept of crisis in capitalism, and traces the way intellectuals and masses deconstruct knowledge of one another. In line with this, Bellow advocates that knowledge is acquainted with struggle, satire, deconstruction, subversion, laughter, philosophy and skepticism. In his introductory note to the play, he pinpoints that: 
[...] The Last Analysis, its real subject is the mind's comical struggle for survival in an environment of ideas-its fascination with metaphors [...] in The Last Analysis a clown is driven to thought, and, like modern painters, poets and musicians before him, turns into a theoretician. I have always had a weakness for autodidacts and amateur philosophers and scientists, and enjoy observing the democratic diffusion of high culture. Regrettably, the broad way version neglected the mental comedy of Bummidge and his family and I have tried to restore it. (Bellow, 1965, p. vii-viii)

Bellow reveals that his play is about the crisis of knowledge in the age of science where its main subject is "the mind's comical struggle for survival in an environment of ideas-its fascination with metaphors." The state of mind that undergoes comical struggle is an abstract figure that develops through metaphor, and traces the struggle and survival of ideas. Satirically, it envisions a clown that is driven into thinking, becoming a theoretician. The crisis of knowledge appears to be the reason behind this "democratic diffusion of high culture." High culture is degenerated under the name of democracy and capitalism. Bellow informs that masses and common people neglect and ignore this "mental comedy of Bummidge and his family;" and, thus, it is his duty "to restore it."

Bummidge and Winkelman -the main subjects in the play- overemphasize Bellow's claim by addressing man's intellectual faculties. The dialogue develops as follows:

-Winkelman: ... some people are social climbers. You are a mental climber. I am not against thought, but you're a comic, not a scientist. Is this a time to plunge into theory? Originality? Delirium! (p. 5)

-Bummidge: ... I look frightful. Can people accept my message of sanity and health if I look like death or madness? ... I want the comedians to see how the analysts laugh. I want the analysts to see how seriously the comedians take me. I must reach every one. Everything. Heart, reason, comic spirit. I have something tremendous to say. I want to persuade them. Move them. Stun them [...] Oh, Imogene, I'm frightened. My fingers are freezing. (pp. 14-15)

The Last Analysis does not provide any analyses nor does it offer any sense of 'intellectual restlessness.' It epitomises the intellectuals' worry about the roots of American culture as well as the role of capitalism in the formation of collective culture. The subjects are 'mental climbers,' comic figures and mad intellectuals, Bellow assures. In the play, Winkelman calls Bummidge "a mental climber, a comic [and] not a scientist." He mocks the age of no knowledge which is not suitable "to plunge into theory and originality." It is "the age of Delirium." Bummidge intensifies this worry as he "look[s] frightful." He wonders if others accept the "message of sanity and health [when] [he] look[s] like death or madness." Differently put, he seeks to achieve wisdom and humanism out of madness and deconstruction. He addresses "comedians and analysts, heart, reason and comic spirit to persuade them, and move them."

Bellow suggests that the metaphysical reason is exhausted, while knowledge is facing a tragic fate. The way to sanity, one should admit, could only be achieved through the way of madness and marginalization. Knowledge, therefore, is only to be understood in line with no knowledge or after knowledge. In Lyotard's terms, the play conveys scepticism, humour and crisis by sketching the ceaseless conflicts between Bummidge, Max (his son) and Bella (Bummidge's estranged wife). In his article, "There is simply too Much to Think about", Bellow posits the issue of knowledge by asking "what should I know to help promote myself and my country" (Bellow, 1995, p. 170)? Although the question overtones a Kantian moral and ethical ring, it firmly grounds the problem of knowledge in postmodern American context. The author responds by raising problems of "Atomic energy, environmentalism, women's rights, homosexual rights [...] imperialism, colonialism, exploitation, harassment, [...] communism, fascism, capital punishment, politicians, their advisors, history and evolution" (pp. 171, 172, 174). To his mind, the representatives of knowledge should advocate that the underlying hypothesis behind the crisis of knowledge already exists in the plastic and programming nature of human being. Bellow asserts that:

The underlying hypothesis [of the crisis of knowledge] seems to be we human beings, considered as material, are totally plastic, and that the material of which we are made will take any shape we choose to give it. A less kindly word for it is 'programming.' The postulate is that it is necessary to reject what we are by nature, that given, the original, the creature of flesh and blood, is defective, shameful, in need of alteration, correction, conversation, that this entity, as is, can contribute nothing, and that it would be better to remake us totally. (p. 175)

The crisis of capitalism is the root cause of the crisis of knowledge. Humanism is equated with materialism and the culture of image, business, superficial ends and risk. Materialism shapes human life, programs it, and rejects the natural and the original. Bellow discusses the example of Michael Jackson who offers an emblematic instance of the crisis of knowledge. The late singer's attempts to change his 'identity' which he ended up being the 'other' to his black community. He devotes his body to explore new frontiers of human identity, and this triggers off 
unexpected moments of scepticism towards consciousness and truth. Jackson's daring gesture, to Bellow's opinion, results in 'creating a new mind' that "transcends the limits of heredity, nature and traditions, and goes beyond all limits and all obstacles" (p. 173). This type of discourse develops in line with Davis's findings concerning the after poststructuralist concept of knowledge, and he identifies knowledge with "[...] incomprehensible jargon, scientific prestige of absurdities, the indecision of thought, obscure terms which are not defined and which are used, elastic notions and too open concepts, the crisis of "contemporary' cultures, the decline of civilization [...]" (2004, pp. 10-18). The heroes crucially disagree about fundamental values, and vehemently attack the grounds which support the critical validity and the intellectual authority of both metaphysics and Enlightenment.

\subsection{Herzog, Sammler and Citrine in the Crisis of Capitalism}

Herzog, Sammler and Citrine maintain that the crisis of capitalism and democracy in modern and postmodern America engenders the crisis of knowledge. Through these intellectual protagonists, Bellow purports to subvert the deconstructive principles of capitalism. Herzog argues that the crisis of knowledge triggers off the crisis of civilisation. In this, the indecision of thought, the ups and downs of mind/reason are usually acquainted with the booms and declines of civilizations. One of Herzog's famous imaginary letters reads:

Anyway, Shapiro, I was in no mood for [discussing] the hidden fate of Man. Nothing seemed especially hidden-it was all painfully clear [...] I think [we] must have started that seminar [...] on the decay of the religious foundations of civilization. Are all the traditions used up, the beliefs done for, the consciousness of the masses not yet ready for the development? Is this the full crisis of dissolution? Has the filthy moment come when moral feeling dies, conscience disintegrates, and the respect for liberty, law, public decency, all the rest, collapses in cowardice, decadence, blood? Old Proudhon's visions of darkness and evil can't be passed over, but we mustn't forget how quickly the visions of genius become the scanned goods of the intellectuals. (Bellow, 1964, pp. 95-96)

Herzog informs that the fate of human being is no longer hidden, it is painfully clear. The diminishing role of religion and the death of God, to recall Barthes, results in "the decay of the religious foundations of civilization." In the late age of capitalism in America, "the consciousness of the masses is not yet ready for development." It is the "full crisis of dissolution," Herzog admits. The decline of civility and the agony of the intellectual have come "when moral feeling dies, conscience disintegrates, and the respect for liberty, law, public decency, all the rest, collapses in cowardice, decadence, blood." Bellow maintains that the visions of intellectuals become fundamental in the deconstruction of the nihilism of capitalism and the subversion of its absurdity. The wisdom of his intellectual represents a starting moment of consciousness about the filthy roots of American culture.

Herzog demystifies that 'the hidden fate of Man' is unavoidably related to the illusive foundations of knowledge. As being subversive and deconstructive in its nature, the knowledge of the bourgeois society in Europe during the eighteenth and the nineteenth centuries has dissolved and turned to be obscure jargon. The revolutionary ideas of Marx, Hegel and Comte proved their failure (p. 96). The empires of Britain, Germany and France have declined and eventually ended up with tragic wars (p. 97). The aristocratic dignity of the old regimes, the utopian models of antiquity and the moral theories of the Enlightenment are now being replaced by racism, nuclear threats, marginalization, exploitation, sexism, new imperialism, homophobia, terrorism, fear, illusion, false thinking and no truth (pp. 172-173). Conscience disintegrated; moral feelings died; and the respect for law, liberty, public decency collapsed. In a typically Foucauldian move, Herzog asserts that madness/insanity is the main source of 'no knowledge' in the after postmodern era, suggesting that "[...] clinical psychologists might write fascinating histories" (p. 99), and interestingly offers a brief historical account on the factors that serve to produce a subversive form of knowledge:

Melancholia in the Middle Ages. Schizophrenia in the eighteenth century. And then this Bulgarian, Banowitch, seeing all power struggles in terms of paranoid mentality - a curious, creepy mind, that one, convinced that madness always rules the world. The dictator must have living crowds and also a crowd of corpses. The vision of mankind as a lot of cannibals, running in packs, gibbering, bewailing its own murderers, pressing out the living as dead excrement. (p. 99)

Psychotherapy and paranoia, as manifestations of twentieth century capitalism, dominate the intellectual scene. The authority of religion and morality diminishes in favor of psychotherapy. Psychotherapists, psychoanalysts and psychiatrists appear as new group of experts who replace religion and morality. Most of the mad minor characters go to therapists to solve their problems instead of church. Herzog and Madeleine frequently visit Dr. Edvig to get advice about their marriage. Phoebe Gersbach goes to her own psychiatrist to get counseling about her husband's betrayal. Himmelstein gets psychic treatment because of his daughters' waste of money. America becomes a country of "psychiatric imperialism" (Lasch, 1991, p. 163), where "the psychiatrist takes a priest's place, a 
doctor's place, the place of the self-reliant individual, and becomes a modern god" (Rho, 1999, p. 43), and where the masses pay too much money to diagnose their mental problems. Psychoanalysts, psychiatrists along with the masses create a culture industry out of psychotherapy which standardized American society.

Bellow deconstructs this capitalistic culture which aims at systematizing human mind. He doubly satirizes psychotherapists: first, as their being ignorant of their profession, and second, as their being money grabbers and metal climbers rather than real intellectual doctors. Sardonically enough, Bellow does not call doctors in the field of science intellectuals, but experts. Dr. Edvig pretends to master the field of psychotherapy, and summons Freud in discussions with his patients. He explains every client's mental problem with paranoia, about which he ironically does not know anything. He acts like an expert with his clients, and prepares a ready list of words to diagnose his clients "Pride, Anger, Excessive 'Rationality,' Homosexual Inclinations, Competitiveness, Mistrust of Emotion, Inability to Bear Criticism, Hostile Projection, Delusions" (p. 77). Bellow mocks him, considers him a fake doctor who cannot tell the difference between real and spurious patients. He legitimizes the betrayal of Madeleine and Gersbach to Herzog; he diagnoses Madeleine as religious, Herzog as patient suffering from paranoia, and Gersbach as a wise helper character.

Edvig and Himmelstein are good representatives of the capitalistic culture with its fake knowledge. They have the characteristics of what Lasch calls the "new elites" in his The Revolt of the Elites (1996), "their livelihoods rest not so much on the ownership of property as on the manipulation of information and professional expertise" (p. 34). They harm the masses, and do not provide them with any service as experts. They manipulate intellectuals, make money out of rich, tell lies to the masses, and pretend to be knowledgeable and educated to their colleagues. In their conversations with their clients, they first discuss the amount of money they have to pay to do the job. They theorize for one dimensional society which equates between the intellectuals and the masses, the high culture with the low culture. They assure the hegemony of materialism and the death of God and morality. Herzog, like Bummidge in The Last Analysis (1965), mocks therapists, psychoanalysts and experts in general as they only generate the crisis of knowledge. More strikingly, he refers to the metaphor of the perpetual death and resurrection of civilization (p. 248) to confirm that philosophers like Hobbes and Hume fail to understand the nature of the human being, which unfathomably affects the quality of the knowledge they produce. Herzog, therefore, epitomizes a world in a state of crisis where the subject remains unable to trust his knowledge, culture and civilization. Throughout the whole story Herzog struggles to deconstruct the ethics of capitalism, and replace the Western philosophies in American mass culture. In capitalistic democracy, culture is very cheap, unrefined one, a junk culture, a kingdom of frivolity and entertainment. Herzog watches "the uptown public, its theatrical spirit, its performers -the transvestite homosexuals painted with great originality, the wigged women, the lesbians looking so male you had to wait for them to pass and see them from behind to determine their true sex, hair dyes of every shade" (p. 179). He feels spiritual nausea for this fake culture with its dirty theatre and mad actors.

The thematic plot helpers and young generation characters in Mr. Sammler's Planet (1970) represent an epistemological break with the old forms of knowledge. They deconstruct the past as represented by Sammler and Dr. Gruner, and establish a new form of knowledge based on capitalistic democracy. They belong to the main stream of American society, and they seem to be happy with its culture. They enjoy every aspect of capitalism and democracy, and ignore grand values of morality and humanism. They create one dimensional and conformist society; and while they are biologically alive, still they are emotionally, spiritually and morally dead. Sammler is not conformist. He deconstructs this culture, and criticizes his society with its capitalist premises. Walter Kaufmann intensifies Sammler worries "Who is more alienated -a writer in America who in1970 does not have a television set, or one who spends much of his leisure time watching television? The nonconformist is obviously alienated from his society, but perhaps those who conform are alienated from themselves" (p. xxxviii). Seemingly, the writer who does not have a TV set is alienated from society and mass culture, while the masses that have all means of entertainment are alienated from themselves. The first category is aware of its alienation, while the second is not, and this aggravates its tragic fate under capitalistic democracy.

Bellow reveals that modern and postmodern form of knowledge is that for and of the young generation. It creates a standardized, one dimensional, amoral and fake society, a society without civility, and excludes intellectuals from the center of American cultural scene. Bellow deconstructs this culture, and maintains its being the logical aftermath of capitalism and the radical socioeconomic and political changes that have occurred in America in the 1960s and the 1970s. Sammler attacks the youths in the novel, considers them narcissistic, hedonistic, ignorant, standing for the symbol of sexual wanton. They are introduced in the context of the stormy sixties in America, the New Left and the hippie culture, a rebellious culture that opposes the established norms. This crisis of knowledge and bankruptcy of capitalism is summed up in the idea that "the entire system of Western society, built upon Aristotelian logic, the Judeo-Christian ethic and upon a series of economic systems from Hobbes to Marx to 
Keynes, does not work" (Miller, 1991, p. 79).

Why do the young generation of the late sixties and early seventies create a culture of after knowledge, and deconstruct the classical, humanistic and utopian Western version of culture? Sammler is a man of knowledge who is trained in European humanistic culture and philosophy. He escapes the German totalitarianism under the Nazi regime to totalitarianism in America controlled by the uncivil crowd. America has become a place of massive industrialization, where production, materialism and business become the only existing value. It has become a place of microeconomics and culture industry that take over the world. The youths, therefore, develop their theory of counterculture loyalty, while Sammler finds it boring, deconstructive and authoritarian. Angela illustrates this counterculture through her gaudy clothing, psychedelic posters, decorated car, group sex and sexual party games, raising the slogan "if it feels good, do it, as long as it doesn't hurt anyone else" (Bellow, 1970, p. 20). She wears a yellow undergarment and "a microskirt, a band of green across the thighs," and the dress shows "sexual kindergarten dress, Baby Doll costume" (pp. 295, 300). Wharton Horricker, Angela's boyfriend, epitomizes this image-based culture. He is found of imported European clothes, buys the latest fashion, and is punctilious in keeping his body in shape. He is "a physical culturist (tennis, weight lifting). Tall, from California, marvelous teeth [...] extremely critical of other people's clothes [...] Once when he thought her (Angela) improperly dressed, he abandoned her on the street" (p. 68). He is a representative of the "cult of masculine elegance," and Angela both of them exemplars of athletic beauty (p. 69). Sammler regards them hedonistic, and considers the countercultural movement behind them vulgar, profane and barbaric.

Bellow deconstructs the culture of the New Leftists and the hippies, and rejects their new form of knowledge. In a interview with Robert Boyers, he reveals "I began, in the late 50's, to think about leaving the eastern seaboard, because I didn't want to belong to any of the gangs, and I felt the madness of the 60 's will be remembered as the decade of frenzy, and violent agitation, having very little to do with literature or art" (p. 13). He informs that he escapes dictatorship and gangs of the East in the late 50s only to find it in America in the 60s. It is a decade of madness and violent agitation which has nothing to do with arts and humanities. Sammler believes that the cultural rebellion in America is only an extension of the gangster politics in Europe, and the only "difference is that the gangsters were a few dictators in Europe, while they are the crowds in America" (Rho, 1999, p. 81). The young characters in the novel live the cultural values of the hippies, smoke marijuana, engage in liberated sex, and live communally. Angela and Horricker demonstrate this as they make sex on the beach with a striking carelessness. Heongyun Rho describes them as follows:

The New Leftists in the novel are ignorant, mean, philistine, and dirty. They have no respect for the elders, or even for themselves, no civility, no nobility, no dignity. Once Sammler employed several university youths to help him study, but they were found to be completely without culture or any real education, even if they did attend Columbia University. (p. 81)

Sammler ascribes them with a very negative image. They are seen "with the big dirty boots and the helpless vital pathos of young dogs with their first red erections" and of "sex-excrement-militancy, explosiveness, abusiveness, tooth showing, Barbary ape howling" (Bellow, 1970, pp. 37-43). When he lectures on liberal arts in England in the 1930 's, one ignorant dirty leftist regarded with great indifference and boredom shouts at him without manners, "Hey! Old Man! [...] What you are saying is shit," and addresses the audience, "Why do you listen to this effete old shit? What has he got to tell you? His balls are dry. He's dead. He can't come" (p. 42). The audience expects a lecture on modern violence, sex, New Left and hippie values, science and risk in business, and not Sammler's old fashioned boring topic. The student's resentment at Sammler epitomizes the death of value, the lack of respect to intellectuals, the ignorance of the student and the bankruptcy of the system of knowledge.

Sammler interestingly discusses the transplantation of the European culture in America. Conservatives and intellectuals enjoy this topic, while youths protest, and criticize Sammler's anachronism. Sammler informs that most of the Frankfurt School scholars immigrated to America because of the threat of the Nazis. Half of them were Jews and connected with Columbia University. They transplanted the European culture in America. Most of them stayed in America after the end of the war, but some of them decided to return to Germany because of the cultural disappointment Sammler experiences in the novel. The quality of education has degraded the system of knowledge.

Wallace and Feffer are graduated from Columbia University, but their contribution to knowledge is contrary to their famous university. Wallace is interested only in sex, money, and imported clothes. He examines his secretary's breasts in his law office instead of practicing the law. At his father's death, he talks about sports statistics with Gruner's physician, Dr. Cosbie, an ex-football player and gambler. He makes efforts to solve the crossword puzzle in a magazine. He is, as Gruner says, "a high-IQ moron" (p. 177). He is a man of everything 
"Wallace nearly became a physicist; he nearly became a mathematician [...] nearly a lawyer [...] nearly an engineer, nearly a Ph.D. in behavioral science [...] Nearly an alcoholic, nearly a homosexual" (p. 88). Feffer is the other version of Wallace. He is a fake intellectual. He enters Columbia University though he does not deserve it. He quotes Aristotle's Metaphysics without understanding the philosopher. He organizes a seminar at the university, and ignores Sammler upon his arrival. He uses his brain to make money cunningly, to sexually exploit his assistant Fanny. He is "a hustler, go-getter, philanderer, public relations personality, always looking for some kind of finder's fee, full of new ideas, comically plans to make it in materialist America" (Venkateswariu, 1990, p. 127). When he takes a picture of the black pickpocket's stealing "not out of rationalist inquisitiveness but for his own material benefit and self-aggrandizement, the final extension of the privileging of self-characteristic of the Enlightenment, intensified and externalized in capitalist, consumer-oriented America," and makes the pickpocket "a commodity to be framed, packaged, and sold to Look" a popular magazine, to satisfy the masses' curiosity (Goffman, 1997, p. 722). Wallace and Feffer are manifestations of American democratic capitalism that values business and worldly desires.

Bellow provides another good instance of the crisis of knowledge by offering an intellectual reading to the history of wars in Ravelstein (2000). The storyteller begins the story by referring to history as a footnote in writing (his) story (Bellow, 2000, pp. 2, 3, 4). The narrative develops quickly to trace the political context in Russia before the revolution, the life of the Kaiser, the Peace of Versailles, the German generals, Hitler and the Nazi party, the Allies and the Americans [...] (p. 7) as fundamental moments in the archeology of knowledge/history. Marx's concept of 'struggle' and Foucault's theory of 'genealogy and archeology' find their way in explaining the way Ravelstein has intellectually interpreted the construction and the deconstruction of civilizations. The financial crisis during the 1930's was the product of the 'liberal/democratic and just' struggle between the empires to dominate the world. "The German bankers' inability to meet the demands of France and England" (p. 8) unavoidably resulted in the Great War, 1939-1945. Accordingly, the war, which is once valorized by Asa Leventhal in Dangling Man (1947), turns out to be a moment of change, a 'new' consciousness, reconstruction and after knowledge to recall Karl Jaspers. When Bellow advocates that the 1948 war led to the emergence of a new state, Israel, in To Jerusalem and Back (1976), Ravelstein confirms this by referring to the newly emerged states after the war. Sammler takes the idea further by overemphasizing an epistemological break from the classical thoughts and the appearance of what Bruce Joseph Borrus calls "the no knowledge or the new strategies of the self" (Borrus, 1995, p. 1). What Walter Bigler refers to as "figures of madness" (Bigler, 1995, p. 7), or what Heongyun Rho assumes as "alienation of intellectuals" in Bellow's novels would be effectively understood interchangeably with Foucault's view to the function of intellectuals in their ceaseless attempts to investigate the structures of thought/knowledge. This intellectual commitment generates a cute awareness of the necessity to re-evaluate and re-write our knowledge, beliefs and structures of thought to borrow the term once again from Foucault. By this token, it becomes clear that Bellow has been endlessly striving to revise the already established certainties and assumptions of knowledge.

Citrine depends on the knowledge of business men and risky people. This concurrently shows the domination of the values of capitalistic democracy, and the attempts to deconstruct them. As previously mentioned, Citrine calls George Swiebel, Alec Szathmar, and Pierre Thaxter reality instructors, and he unfathomably depends on their helpfulness and advice. They are proven to be ignorant, dirty, opportunist and materialist. Swiebel, a man of business, in contact with radio, television and journalism, teaches Citrine the way to get rid of stress. Citrine feels happy temporarily, and in the end, he cannot accept his reality. Again, Swiebel represents the voice of media, and metaphorically stands for the masses in modern America. He teaches Citrine the way to deal with divorce case, how to counter a gangster, how to cure from physical pain without taking medicaments. Citrine says, "When I'm in despair he's always the first person I telephone" (Bellow, 1982, p. 49). Swiebel dominates Citrine, and shows the death of value and the crisis of knowledge. Citrine appears to be weak, impractical, aloof, utopian, much like Humboldt, and in need of help and advice.

Szathmar attacks Citrine's values by introducing Renata to him. She is a sex model, and Szathmar advises Citrine to be practical with her. "In his chair his posture suggested clumsy but unshakable sexual horsemanship top pretty ladies" (p. 207). He presents himself as a man of reality, and advises Citrine to be practical, and belong to the masses. He assures him that sex with Renata would make him forget his failures, and cure his idealism.

Pierre Thaxter pretends to be a man of culture, and Citrine describes him as follows:

Pierre Thaxter was absolutely mad for Culture. He was a classicist, heavily trained by monks in Latin and Greek. He learned French from a governess, and studied it in college as well. He had taught himself Arabic also, and read esoteric books. He played Stravinsky on the piano, knew much about the Ballets Russes. On Matisse and Monet he was something of an authority. (p. 251) 
Thaxter appears to be a man of culture who reminds Citrine of his sibling, Humboldt. He is trained in classic and Greek knowledge. He knows French and Arabic, reads esoteric books, and plays on piano. In short, Citrine thought, at first glance, that Thaxter is another Humboldt who may cure the problem of knowledge, and build a new culture in America. However, he ironically turns out to be a fake intellectual, materialist, opportunist, liar, who uses Citrine. Rho says:

He is a leech bloodsucking Citrine. He wastes Citrine's money, not editing the magazine, but purchasing all manner of non-intellectual and high grade goods -special wine, a special bed, a special TV, special food, first class air tickets, a cruise ticket, high-tech computers, luxury furniture, a Cadillac, a specially ordered umbrella handle, etc. (p. 125)

He represents the newly emerging bourgeoisie; he lives and spends like aristocrats. He is eager for sexual adventures, and trying "the flesh" of all sorts of the ladies he meets. Citrine feels betrayed and eluded by Thaxter in specific and the social class he stands for in general. Bellow, behind this, intensifies the crisis of knowledge in capitalistic democracy of modern America.

Julius, Citrine's brother, is another example of capitalistic democracy and crisis of knowledge in modern America. $\mathrm{He}$ is a man of business, action and practical things. He builds apartments, bridges, buildings, and thereby changes the image of America physically, unlike Citrine who is man of ideas and theories. Julius is a man of present and future; he is the man that America needs most, and he advises his brother "if you had to be an intellectual, why couldn't you be the tough type, a Herman Kahn or a Milton Friedman, one of those aggressive guys you read in The Wall Street Journal!" (Bellow, 1982, p. 384). To Julius, successful people should be like Khan and Friedman, two famous American economists, and not men of abstract ideas like his brother.

Citrine cannot cope with the directions of his brother, nor can he use the advice of Thaxter and Szathmar. He escapes to the mysticism of Rudolf Steiner and Owen Barfield. Bellow deconstructs the cause root of this cultural backdrop. He diagnoses human beings' unhappiness as a result of technological development and secularization. He admits that capitalistic democracy deepens the crisis of knowledge, and generates an atmosphere of alienation and decline of modern America. And it is because of this that his intellectual protagonists deconstruct and subvert the fundamental premises of capitalism.

\subsection{Corde, Henderson and the Layers of Dictatorship}

The crisis of capitalism and the problem of knowledge in Humboldt's Gift (1975) are envisaged through Corde's suffering from layers of dictatorship. Corde shows a critical awareness to the bankruptcy of capitalism and its very negative effects on the archeology of American mind and society. In Romania he suffers from the bureaucracy of the communist system, the dictatorship of the general, the surveillance system and the decline of civility. When he returns to America, he tragically finds more dictators of another sort. He addresses Mina, "it is the weak democracies that produce dictatorships. Or that our decadence is heading full speed towards decadence" (Bellow, 1982, p. 20). Corde maintains that those who take the place of Ceausescu in America are the vulgar masses and mass media. They produce a low culture based on material things and image; they pursue a life of worldly desires and of "momentary pleasures, spend every day noisily and boisterously like actors on TV, and have big emptiness within" (Rho, 1999, p. 63). Max Detillion, Corde's cousin, is a good example in this case. He belongs to the masses, defends them, and speaks in their names. He is a lawyer who defends Lucas Ebry not for the sake of justice, but in order to advertise his career. Corde comments, "Win or lose, it was bound to improve his reputation. Chicago is still more his scene than it is mine" (Bellow, 1982, p. 279). He behaves in the court like a leading actor; he gives orders and directions. Corde reveals his addiction to sexual adventures; he stresses his belonging to the hippie movement of the sixties. Corde aggravates thereby his debauchery, "if he should ever be elected to office, he wouldn't put his hand on a Bible to take the oath, he'd put it on his cock" (p. 147).

Corde reveals that dictatorship and the practices of capitalistic democracy can be seen in the court of Chicago. The place, according to the masses, is no longer seen as the symbol of justice and equality, but a place where deals, bribery and sexual attractions take place. In the court, lawyers such as Max Detillion and Sam Varennes work to make money, empower their connections, and not practice the law. Varennes proves to be stupid, ignorant, and incapable of practicing the law with limited insights about his profession. He defends Spofford Mitchell, a black rapist and killer, and instead of practicing a scientific investigation of the crime and looking for proofs and details that can help him understand it, he approaches the case from the traditional myth that blacks are obsessed with raping a white woman. Billy Edrix, Corde informs, wants to divorce his wife who is accused of attempting to kill Edrix, and legally proved guilty of that. However, the court orders him to be responsible for his wife until divorce is completely settled. Edrix rejects the ethics of the court, and Corde assists him, and confesses its being inhuman, illegal and illogical. Corde is apathetic about this, while Bellow explicitly rejects this phenomenon, and 
deconstructs its root cause, capitalism.

Corde confesses that Max has used and abused him. This metaphorical image stands for the perpetual conflict between capitalism and intellectualism, the masses and the intellectual, business and ethics. Corde tells Elfrida, his sister, about it:

"I dropped a lot of dough on him. Let's say I was paying tuition. I had to take a special course."

"Learning what, dear?"

"Things I should have known fifty years ago. A postgraduate seminar in bone headedness and idiocy."

"Maybe a quarter of a million wasn't tuition enough."

"I see what you mean. Losing that much dough didn't make me suffer enough.

' $m$ still an idiot, and I haven't got the dough to enroll in another course." (pp. 97-98)

Corde rhetorically reads her reaction to his confession. He says:

He was sounding out his sister on the Chicago articles, trying to get her opinion. Did she see those disturbing pieces as his new venture in idiocy? [...] She was perhaps as sorry for her brother as he was for Cousin Max. She believed he was a very strange man. His hang-ups were not like other people's [...] he had his own most original, incomprehensible way of screwing things up. (p. 98)

Max takes Corde's money in order to establish a magazine, but he fades away. He spends the money on his personal desires, and ignores Corde. Elfrida feels sorry for her brother, but she does not dare to express it openly. Corde contemplates at her, and reads her inner thinking. Bellow reiterates that Max represents the failure of liberal education and the fake intellectual in the late 1960s and the early 1970s.

Mason, Corde's nephew, is another dictator in democratic America. He is an epitome of the rebellious and militant student in the sixties. When he argues with Corde because of Lucas Ebry, his intention is to confront with his uncle and not look for justice. Corde for him stands for the symbol of the authority of the school, and it is because of this that he rebels against him. Rho describes this conflict in terms of power and subversion, he says, "Mason makes his own scenario about how the murder case has happened, and Corde has his own too. But the key point is not the truth about the homicide, but the conflict between student and university as authority, black and white, radical and conservative, culture and counterculture" (Rho, 1999, p. 166). Mason maintains that Lucas Ebry is real, while others are not including his uncle who lives only through and by seminars about Plato and the Good. He rejects his uncle's superior and racist view about those people of the underclass who are considered dopers or muggers and whores. Mason regards his uncle and the social category behind him "thinking population and establishment intellectuals," who admit that the masses and the rest of people "are nothing but mice!" (Bellow, 1982, p. 36). Corde is the representative of high culture, while Mason is a representative of the people of the street. Ebry is his comrade in the communist party. He intends to teach his ignorant uncle some lessons about Chicago's social reality. He had earned the right to speak for the oppressed because he and Lucas Ebry had worked together in the grease and garbage of the kitchen, sweat rags tied on their foreheads (p. 35).

Henderson illustrates Corde's attitude towards the layers of dictatorship and capitalism in America. He reveals that his suffering and chaos are the result of his not being what he really is. He regards himself as other to his society; and his non-being existence stems from his alienation in capitalistic democracy of America. Differently put, he regards himself not in terms of belongingness but rather in terms of difference in an environment of "others, parents, wives, girls, children," who are not identical to himself. He confesses that "Society is what beats me. Alone I can be pretty good, but let me go among people and there's the devil to pay" (Bellow, 1959, p. 9). Henderson means by society the masses, mass media, experts, journalists, lawyers, and doctors who are guided by money, business and risk principle.

Henderson's "chaotic condition" envisages the human condition in America in the sixties in which one feels separated from one's real being. Heidegger calls it "fallen" or "inauthentic." Sahakian describes Heidegger's view of the inauthentic as follows:

Dasein is authentic when he is something of his own, and inauthentic when he is busy, excited preoccupied. Inauthenticity is to be distinguished from the authentic self by being recognized as a they-self, that is as the group self, the public self, or as a part of the social existence into which the self is dispersed, falling into anonymity and depersonalization. Having fallen (fallenness) into inauthentic Being, such an individual is susceptible to publicness. (Sahakian, 1959, p. 350)

Henderson has fallen in his society with its capitalistic premises. Bellow maintains that Henderson's authentic self 
has dispersed itself into the form of body spirit in which he now exists. Henderson deconstructs the ethics of society in New York in order to regain his real being. His literal world, his irascibility, music lessons, eccentric tendencies, and constant activities become outer symbols for a state of mind that needs to be changed. Henderson runs away from all aspects of material life in New York, the different sorts of dictatorship in order to exist as an authentic being in the world. His alienation and his being other in his society deepen his ontological, existential and philosophical loss, and provide him with a rationale to struggle against conformity. He says, "When things got very bad, I often looked into books to see whether I could find some helpful words, and one day I read, 'the forgiveness of sins is perpetual and righteousness first is not required.' This impressed me so deeply that I went around saying it to myself" (Bellow, 1959, p. 3). "Forgiveness" with no required "righteousness" removes all personal responsibility of the self. It reduces the self to a passive entity. Henderson struggles to deconstruct the outer world, admitting "It was a question of spirit, too, for when it comes to struggling, I am in a special class. From the earliest times I have struggled without rest" (68).

Bellow has given a particular emphasis to the decline of the capitalistic ethics in America and its results on culture and society. From the beginning of the novel up till the end, he depicts Henderson's suffering from an acute awareness of the ailments of the masses, the reckless economic system, the death of civility and the philosophical infirmities which characterize his existence. One senses in him a morbid depression of the spirit and an alienated existence. In her Ontological Perspective Applied to the Interpretation of Saul Bellow's Henderson the Rain King (1977), Judy Lee Svore envisions Henderson's conflict with his society, and his attempts to deconstruct its ethics. She says

The feeling of a compulsion to grief leads him to battle drunkenly with the state troopers of Danbury, Connecticut, to argue with his wife, Lily, to alienate his son and daughter, to refuse his tenants heat during the winter, to fire his forty-five revolver at their cat, and to rage and shout in such a voice that the elderly maid, Miss Lenox, succumbs to a heart attack. (p. 94)

Henderson decides to subvert the ethics of the masses including his wife, Lily, his son and his daughter. From a community or external, family perspective, Henderson's behavior is unpredictable, irrational, and frequently violent. He shouts at the elderly maid, Miss Lenox, and causes her a heart attack. He is regarded as mad, eccentric, misdirected and alienated in his society. One reaches the conclusion that such an extremely-violent behavior stems from his need to distance himself from the "others" in order to save his own awareness of being. That the masses lack a full sense of being is apparent in the way they subordinate their existence to their function. Differently said, they know themselves only through the economic function they perform; this intensifies the tragic condition of modern man, labels and negates the authentic self.

Capitalistic democracy in America displaces Henderson who regards himself as inferior in value and economic function to his pigs. He says, "Even the pigs were profitable. I couldn't lose money. But they were killed and they were eaten. They made ham and gloves and gelatin and fertilizer. What did I make? Why, I made a sort of trophy, I suppose. A man like me may be something like a trophy" (p. 24). Sardonically, Henderson confesses his awareness of being useless in attempting to discover the authenticity of the self in his society. He informs:

What do you do with yourself if you have a temperament like mine? A student of mine once explained to me that if you inflict your anger on inanimate things, you not only spare the living, as a civilized man ought to do, but you get rid of the bad stuff in you. This seemed to make good sense, and I tried it out. I tried with all my heart, chopping wood, lifting plowing, laying cement blocks, pouring concrete, and cooking mash for the pigs. On my own place, stripped to the waist like a convict, I broke stones with a sledgehammer. It helped, but not enough. Rude begets rude, and blows, blows; at least in my case; it not only begot but it increased. Wrath increased with wrath. (p. 23)

Capitalism acquires Henderson animalistic features as he compares himself to once animals, pigs, and another time ascribes violence and wrath to his behaviors. He celebrates the profitability and productivity of animals and the uselessness of human beings including himself. This kind of nihilistic and absurd existence, as the main result of the negativity of capitalistic democracy, triggers off Henderson's deconstruction and subversion, and generates a ceaseless search of the ontology and the authenticity of the self. Through Henderson, Bellow explicitly suggests that the ethics of capitalism in modern American society and culture must be deconstructed and subverted in order to generate a counterculture of humanism and life. From ontological and philosophical perspectives, intellectuals such as Henderson, Corde, Herzog, Humboldt and Sammler should be considered as moral and ethical legislators of their society, while the materialistic ethics of capitalism must be revised.

\subsection{The Archeology of Knowledge and Deconstruction}

Bellow's theory concerning the crisis of capitalism should not necessarily engender absurdity and nonsense. One 
fundamental assumption behind this postulate is that no knowledge, jargon, no order or sense are another different kind of knowledge which requires other insights and means of investigation. This hypothesis might be seen in line with Habermas's theory of the unfinished project of modernity/the Enlightenment. In other words, Bellow's deviation in examining the concept of knowledge by the crisis of knowledge is a reflection of the maturity and the growth of the mind of the author. Therefore, explaining the concept by referring to its opposite is a moment of consciousness of the contradictions inherent in the concept itself, a claim that proves its legitimacy and logic especially when the author shows a careful awareness of the Hegelian strategies of dialectics.

In his recent influential study, Alienation of Intellectuals in Saul Bellow's Later Novels (1999), Heongyun Rho has offered a philosophical response to the previously mentioned remark, and does more than positing a holistic account of that view. On this view, Rho has purported to address Bellow's early beliefs in relationship with the crisis of knowledge, intellectualism, madness, the alienation of intellectuals in relationship with the power of the masses and low culture. Rho, in his desire to disclose the author's peculiar deviations, contradictions, subversion, deconstruction, provides the reader with striking-expected results:

a) The crisis of knowledge crystallizes the maturity of the author which is said to rest on subversion, deconstruction and madness.

b) The crisis of knowledge is to be considered as a fundamental gesture to account for Bellow's view concerning the relationship between the intellectuals and the masses, high culture and low culture.

c) Bellow's philosophy of life largely hinges on intellectualism and mad, wise, alienated heroes to cite Walter Bigler.

Rho and Bigler have attempted to trace the author's intellectual maturity and the way a deconstructionist thought would read a novel. Being convinced of the intellectual context that qualifies Bellow's late writings, Rho does not raise any suspicious questions as to how no/after knowledge constitutes a form of coherent knowledge, assuming this as a form of organic growth of the writer's mind and wor(l)d, and never concedes it is a radical change in the man's writings.

Conversely, the researcher shall suggest that a profound exegesis would offer much more striking results. In this respect, one could obviously remark that Bellow's 'maturity' in treating the issue of knowledge has been achieved through three fundamental phases:

a) In his early writings, the author associated the issue of knowledge with certain social, cultural, political and economic circumstances. When Tommy Wilhelm epitomizes loss, inability to decide and ignorance, this is highly explained and justified by the subject's failure to cope with the 'new' norms of the capitalistic society. Augie's never-ending journeys generate material ends rather than spiritual purposes, while Asa's eagerness to go to the war was infuriated by political intentions.

b) During this phase the author shows a careful awareness of the relationships between the crisis of knowledge, politics, art, representation and intellectualism. In this, the crisis of knowledge was scrupulously envisaged through the critical readings to the Enlightenment ideals. Herzog's revisionist gestures to the Kantian, Marxist and Hegelian moral theory are emblematic instances in the case. Sammler's sharp criticism to the postmodern politics and Bellow's personal accounts and readings to the major issues of the age represent a pivotal moment to the next phase.

c) At this stage, the novelist posits the problem of knowledge anew. He, accordingly, strives to exploit the findings of philosophy, theory and criticism, historiography, aesthetics, art, culture, the histories of empires and civilizations, the human nature, theology [...] to unravel the subversive nature of knowledge. In line with this, Bellow appears to be philosopher, theorist and even historian rather than novelist or artist. More strikingly, this maturity, one acknowledges, has been epitomized not in a chronological order since the reader is highly required to make extra efforts to dig deeper into the concept of knowledge in most of Bellow's writings.

In theoretical terms, the crisis of knowledge curiously brings a deep impulse to liberate the human spirit/mind from classical, intellectual constraints. Expressing a revolutionary impulse to free knowledge from the shackles of ignorance and prejudices that had fettered it for a long time, twentieth century theorists adopted the Kantian motto 'have courage to use your own understanding.' Referring to the Foucauldian assumption which rests on the fact that revolution in thought is always bringing a new form of intellectual immaturity or dogmatism, which in the case of Derrida and Bellow can only engender a better insight into knowledge, Marshall Berman argues that "the concept of knowledge has been always melting into the air" (Berman, 1983, pp. 1-6). The crisis of knowledge, in this sense, is the crisis of the history of ideas, theories, and philosophy. Unlike Foucault and many other philosophers who fail to comprehend the crisis of modernity/knowledge and, and thereby to furnish a way out of it, 
Bellow firmly rejects the kinds of structuralist, poststructuralist and after poststructuralist forms of knowledge, contending that we need to reflect on our age in a way that allows us to regain knowledge in its own roots, which Drolet explains in terms of theory and philosophy "Genealogical history would tell the story of a constant struggle between different powers which try to impose their 'will to truth"' (Drolet, 2004, p. 20). To Derrida, and to a lesser extent Foucault, Drolet informs that the crisis of knowledge is the process that releases us from the status of immaturity; it is, accordingly, the status of never-ending form of knowledge (pp. 12-24). What could be seen as after knowledge to Bellow's mind is indeed a moment of regeneration in the history of the system of thought in the Foucauldian sense. In this way, if The Order of Things: An Archeology of the Human Sciences crystallizes épistèmes as moments of different forms of knowledge, then the Nietzschean On the Genealogy of Morals underpins "the painstaking rediscovery of struggles between different forms of knowledge/épistèmes/discourses, the rediscovery of fragmented, subjugated, local and specific knowledge, the knowledge of marginalized people and groups" (qtd. in Drolet, 2004, p. 20). Derrida radically takes the idea further by advocating ceaseless gestures of deconstruction and subversion to all kinds of knowledge. The kind of experience which Derrida sought to provoke in his strategies of deconstruction is the kind of experience Bellow sought to achieve in his re-reading to the crisis of knowledge. More significantly, Lyotard's reflection on 'the scope of knowledge,' to borrow the term from Kant, goes in line with the author's interpretation to the history of wars, technology, morality, knowledge, and Man. They both assume that:

$[\ldots]$ this kind of knowledge is theorizing its own evolution as discontinuous, catastrophic, non-rectifiable and paradoxical. It is changing the meaning of the word knowledge, while expressing how much the change can take place. It is producing not the known, but the unknown. And it suggests the model of legitimacy that has nothing to do with maximized performance, but has at its basis difference understood as paralogy. (Lyotard, 1984, p. 20)

Curiously enough, these intellectuals provide a good theoretical basis for the reader to investigate Bellow's ambivalent reflections on knowledge, a gesture that strikingly united them in the way they perceive knowledge, things and the world around them.

\section{Conclusion}

Bellow's investigation into the crisis of capitalism in modern and postmodern America, and the way it is argued is both striking and, at first glance, mystifying. Upon a closer inspection, however, its intention becomes clear. Bellow believes that the crisis of knowledge is the result of the crisis of mind, reason, spirit and morality. His stress on the notion of subversion indicates the importance he attached to understanding knowledge with the assumption that 'everything is [already] pregnant with its contrary,' to recall Marx. However, how can it be possible that one could establish a sense of identity within this ambivalent intellectual context? Can it be said that the storyteller is writing his life story without referring to any sort of order or coherence? Can it be argued that the author's view of knowledge influences the way he perceives identity, things and the world around him?

\section{References}

Bellow, S. (1944). Dangling Man. New York: Vanguard Press.

Bellow, S. (1947). The Victim. New York: Vanguard Press.

Bellow, S. (1953). The Adventures of Augie March. New York: Vanguard Press.

Bellow, S. (1956). Seize the Day. New York: Vanguard Press.

Bellow, S. (1959). Henderson the Rain King, New York: Viking Press. https://doi.org/10.2307/3848167

Bellow, S. (1964). Herzog. New York: Viking Press.

Bellow, S. (1965). The Last Analysis. New York: Penguin.

Bellow, S. (1970). Mr. Sammler's Planet. New York: Viking Press.

Bellow, S. (1975). Humboldt's Gift. New York: Viking Press.

Bellow, S. (1976). To Jerusalem and Back: A Personal Account. New York: Viking Press.

Bellow, S. (1982). The Dean's December. New York: Vanguard Press.

Bellow, S. (1989). The Bellarosa Connection. New York: Penguin.

Bellow, S. (1995). It All Adds Up: from the Dim Past to the Uncertain Career. New York: Penguin.

Bellow, S. (2001). Ravelstein. New York: Penguin.

Berman, M. (1983). All that is Solid Melts into Air: The Experience of Modernity. London: Verso. 
Bigler, W. (1995). Figures of Madness in Saul Bellow's Longer Fiction. Diss. U of Zurich.

Drolet, M, ed. (2004). The Postmodernism Reader: Foundational Texts. London: Routledge.

Foucault, M. (1994). The Order of Things. Paris: Guallimard.

Goffman, E. (1997). Between Guilt and Affluence: The Jewish Gaze and the Black Thief in Mr. Sammler's Planet. Contemporary Literature, 38(4), 705-725. https://doi.org/10.2307/1208934

Lasch, C. (1991). The Culture of Narcissism: American Life in an Age of Diminishing Expectations. New York: W. W. Norton.

Lasch, C. (1996). The Revolt of the Elites and the Betrayal of Democracy. New York: W. W. Norton.

Lyotard, J.-F. (1984). The Postmodern Condition: A Report on Knowledge (Trans. Geoff Bennington and Brian Massumi). Minneapolis: University of Minnesota Press. https://doi.org/10.2307/1772278

Miller, T. (1991). The Hippies and American Values. Knoxville, TN: University of Tennessee.

Nietzsche, F. (1969). Thus Spoke Zarathustra: A Book for Every One and No One (Trans., with introduction and commentary, R. J. Hollingdale). Harmondsworth: Penguin.

Nietzsche, F. (2009). On the Genealogy of Morals. Oxford: Oxford University Press.

Rho, H. (1999). Alienation of Intellectuals in Saul Bellow's Later Novels. New York: University of New York.

Svore, J. L. (1977). An Ontological Perspective Applied to the Interpretation of Saul Bellow's Henderson the Rain King. Arizona: The University of Arizona.

Venkateswarlu, D. (1990). Ideology in Saul Bellow's Mr. Sammler's Planet. Panjab University Research Bulletin, 21(2), 125-130.

\section{Copyrights}

Copyright for this article is retained by the author, with first publication rights granted to the journal.

This is an open-access article distributed under the terms and conditions of the Creative Commons Attribution license (http://creativecommons.org/licenses/by/4.0/). 